\title{
THREE STREAMS IN ALTERNATIVE EDUCATION: A PHILOSOPHICAL, PEDAGOGICAL, AND PRACTICAL COMPARISON BETWEEN DEMOCRATIC, WALDORF, AND MONTESSORI EDUCATION
}

\author{
Gilad Goldshmidt ${ }^{\mathrm{i}}$ \\ David Yellin academic College of Education, \\ Oranim academic College of Education, \\ Tel Hai academic College, \\ Israel
}

\begin{abstract}
:
This article examines the three most prominent movements of alternative education in Israel: Democratic education, Waldorf education, and the Montessori method of education. By comparing the educational approaches according to specific criteria, the goal is to provide the reader with as broad a picture as possible of their similarities and differences. The discussion focuses on the philosophical approach and general principles of each movement and does not aim to provide information or characteristics of specific educational institutions. One of the goals of the article is to bring before parents, educators, and policy makers knowledge of the different approaches so that they can understand and judge them with greater clarity.
\end{abstract}

Keywords: alternative education, democratic education, Waldorf education, Steiner education, Montessori education

\section{Historical Background of the Central Approaches and Thinkers}

The movements of alternative education presented in this article, democratic, Waldorf, and Montessori, developed over the first two decades of the twentieth century. Apparently, this period was ripe for educational renewal. Despite the fact that I did not find evidence for mutual acquaintance between the founders and thinkers of the different movements, the spirit of renewal in the field of education flowed through all of them and, it seems, often in the most similar of directions.

\subsection{Democratic Education}

The term "democratic education" is very broad and difficult to characterize and define. Kizel (2012) and Miller (2007) view one educational movement that began with Dewey

i Correspondence: email gilad@harduf.org.il 
and the progressive education movement of the 1920s and 1930s, and continued through what they coin the "second wave" of the 1970s, popularized by the terms "free education" and "open education," until the current wave that began in Israel with the establishment of the Hadera Democratic School in the late 1980s.

Researchers ascribe the first wave to Dewey, but its theory is rooted in the teachings of Rousseau, Pestalozzi, and Tolstoy. Following Dewey's work, the Association for Advanced Education was established in the US in addition, of course, to Dewey's own experimental school at the University of Chicago. In the 1920s, Summerhill School began operating, upon which I will elaborate below. The second wave of progressive education developed due and parallel to the civil rights struggles and to liberation movements in the US and Europe growing out of the Vietnam War, inspired by the thought of Abraham Maslow and Carl Rogers, among others (Hecht \& Ram, 2008). The third wave began as the 1980s came to a close with the founding of the Organization for Democratic Education in Israel and subsequently spread throughout the world (https://www.idenetwork.org).

Historically, one can cite a number of starting points for the democratic movement. For example, Tolstoy's pedagogical theory from the 1860s was the basis for establishing and accompanying 14 schools in his region under the slogan: "do what your soul desires" (Troyat, 2001, p. 241). Tolstoy admired Rousseau and saw, as he did, in the bourgeois intellectual culture of his time atrophy and distancing from the free and pure nature of humans. Tolstoy's educational experiments and his pedagogical writings significantly influenced progressive thinkers of the twentieth century such as Goodman, Holt, and Neill.

There is no question, however, that the first democratic school, in its full meaning, was established in Summerhill by Alexander Sutherland Neill (1883-1973; Neill, 1960, 1972). Neill was born in rural Scotland where his father was principal of the area school and infused their home atmosphere with fear and guilt (Bailey, 2013). After many educational experiences he founded Summerhill School in southern England, which he directed until his death (Bailey, 2013; Neill, 1972). Summerhill was established in 1921, revolutionary then, as it has remained today. From its inception, students had complete freedom to choose whether to attend classes and how to spend each hour of their day, there was a parliament directed by the students, themselves, where they made decisions regarding every detail of school life (which was also a boarding school), and there was full equality between teachers and students (Neill, 1960). I will elaborate on each of these elements below.

Neill was influenced both personally and intellectually by two central thinkers. The first was Homer Lane (1875-1925), an American educator who came to England in 1913. Lane worked in an institution for young criminal offenders and then was invited to be superintendent of an institution for delinquent youth in Dorset known by the name "Little Commonwealth." The second person who influenced Neill deeply was the philosopher, scientist, and thinker Wilhelm Reich (1897-1957). Reich, one of the most unique thinkers of the twentieth century, was born in Vienna and studied medicine, specializing in psychiatry. Reich emphasized the importance of a person's sexual energy, 
both individually and socially, and its repression as a principal cause of mental illness (Mary \& Chester, 1988).

For many years, Neill traveled during school vacations to Reich's clinic in Oslo, conversing with him and undergoing his unique treatments (vigotherapy). He corresponded with Reich until Reich's death and saw in him the continuance of psychoanalytic theory, particularly its proper application to education.

\subsection{Montessori Education}

As its namesake, Montessori education is based on the personality and vision of a singularly special woman: Maria Montessori (1870-1952). Montessori was born in a small town in northern Italy. She excelled in her studies but refused to become a teacher as both her father and her tradition demanded. At the young age of 13 , she began studying at a technological school intended for boys only. After finishing, she completed an academic track that made her a pathbreaker in her time: a degree in science and medicine with specialties in psychiatry, psychology, and anthropology (Montessori, 1988; Standing, 1957).

Montessori was apparently the first woman in Italy to become licensed to practice medicine (Montessori, 1988; Standing, 1957). She specialized in pediatric medicine and psychiatry, working initially at the University of Rome Psychiatry Clinic from 1898-1900. There, during research on people with disabilities, Montessori first encountered children with special needs and methods for treating them. Montessori noted that she immediately felt that the children raised, first and foremost, questions of education and not strictly of medical needs. This experience led Montessori to study philosophy, psychology, and education in order to bring her ideas to her work with children of normal development as well. She essentially abandoned her professional status as a doctor for an unclear future (Montessori, 1988, 1912, ch. 2).

In 1906, after becoming the first woman in Italy to receive the title professor (psychology and anthropology), Montessori was given the opportunity to examine her educational principles and methods in a framework for children of normal development. She received responsibility for "Casa de Bambini", a children's home in the workers' quarter of San Lorenzo, Rome. Casa de Bambini was an educational-therapeutic home for children aged three-seven who came from the lowest socioeconomic condition, most of them neglected, sometimes even starving, with no orderly homelife or history of formal education. This home was the first in which Montessori applied her unique approach to education and learning, and she later founded a number of homes in Italy (Montessori 1988, 1912).

Montessori's focus on educational subjects for peace and brotherhood and sisterhood has been publicized throughout the world, and she has been nominated a number of times for the Nobel Peace Prize. Until her death in 1952, Maria Montessori continued to write books, to teach, and to disseminate her methods in courses and conferences worldwide. 


\subsection{Waldorf Education}

Rudolf Steiner, the man behind Waldorf education, was born in 1861 in a small village in the Austria-Hungarian Empire, today Croatia (Hemleben, 1984). After completing high school with honors, it was an obvious choice to attend the Vienna University of Technology. Upon completing his studies, Steiner began editing the scientific writings of Goethe, first in Vienna and later at the Goethe-Schiller Archive in Weimar (Hemleben, 1984). In 1897, at the age of 36, Steiner moved to Berlin where he was creative and active in a number of arenas. He was appointed editor of a literary magazine and wrote as a journalist and reviewer for a number of newspapers and journals, he lectured to workers in night school and, no less important, lived intensively the bohemian life of one of the most lively European cities of the period.

At the turn of the century, at the age of 40, Steiner decided to publish his spiritual ideas, which until that point he had expressed only circuitously through philosophical writings and reviews on topics of culture and art in different newspapers. Steiner consciously positioned himself as one of the leaders in the struggle against the materialistic thinking that dominated science and culture at the time, a struggle that accompanied him until the end of his life. He began to lecture in Berlin for groups with a spiritual orientation and joined the Theosophical Society founded by Helena Blavatsky, quickly becoming head of the German branch. During this period, Steiner lectured throughout Germany on a variety of spiritual topics and published numerous books on the spiritual essence of the person, his or her development, connection to the hidden face of existence, and more (Steiner, 1998).

After WWI, Steiner lectured before workers at large industrial factories in Stuttgart in the framework of a social change movement that he established. At the "WaldorfAstoria" tobacco and cigarette factory owned by Emil Molt, one of his friends and students, he also spoke about education. His words apparently found a ready ear, and the next day representatives from the workers approached and asked him to establish a school for their children. With the encouragement and support of Molt, Steiner decided to accept the offer and, in September 1919, the first school in the spirit of anthroposophy opened for workers' children, the "Waldorf School” (Hemleben, 1984).

Steiner succeeding in mentoring the school for five years until his death. During this period, he also assisted in establishing additional schools in Germany, Holland, Switzerland, and England. He served as the official school principal, advised teachers, developed curricula, took part in teachers' meetings, and lectured frequently throughout Europe on educational topics.

\section{Philosophical-Theoretical Background}

The alternative educational movements presented in this article originate from different worldviews and philosophical and spiritual backgrounds. This spiritual and philosophical background molded, to a great degree, the educational work of each movement. 


\subsection{Democratic Education}

The educational ideology upon which democratic education stands is the worldview that sees the individual as its center (Egan 1997; Lamm, 1976). Philosophical speaking: to place the child at the center of educational activity, at the expense of socialization and acculturation (Egan, 1997; Lamm, 1976). I have already noted Rousseau, who was the first thinker in modern Europe to place this ideal at the center of his educational approach (Rousseau, 1921).

Neither Neill nor his sources of spiritual inspiration were academics; they even ridiculed academic research in the field of education (Cohen, 1993; Neill, 1972). We are reminded of Rousseau and Tolstoy who believed in the simple nature of the unlearned person, wary of the influence of the powers of intellectual culture on the person. Korczak, despite being a learned doctor, man of books, and author himself, also did not see any purpose in the formal study of education or its research, preferring straightforward observation and the simple, natural connection with children (Silverman, 2017).

Democratic education rested upon ideology of the individual and their development as the most important goal of educational systems and processes, on the one hand, and upon principles of liberalism on the other, freedom and democracy as they developed in western culture beginning with the Enlightenment: "The central question that occupies democratic schools is: What is the appropriate education for a democratic society?... These schools engrave upon their flag democratic values and the ongoing attempt to apply equal rights and obligations, freedom of speech and activity, participation from internal motivation, and participatory decision making" (Hecht \& Ram, 2008, p. 21).

If "democratic values" are the most important, then it is essential to prepare children for this life and to experience them from childhood (Greenberg, 1994; Hecht \& Ram, 2008).

When standing upon these theoretical foundations, one arrives at the following basic assumptions: (1) The child is inherently good and moral, evil does not come from within but from educational and environmental defects; (2) If the child will be free, relaxed, and act firstly and primarily from within, the child's abilities, skills, and all that is latent will be expressed and realized in the best way; (3) Educators must act and influence as little as possible, and definitely refrain from setting a daily schedule or the values and rules they think appropriate; (4) The best framework for realizing these values is the democratic framework; therefore, it is important to actualize these aspects in the life of the school (Greenberg, 1994; Kiezel, 2012).

Democratic education is the product of ideas of the Enlightenment and liberalism as they can be expressed, directly and obviously, through education. In this way, democratic education is the complete, direct application of a liberal world view of adults to the world of children. In relation to the succeeding educational movements, Montessori and Waldorf, it is important to note that democratic education is not based on the fundamentals of science: educational research, educational theories, and methodical, ordered observation of children. 


\subsection{Montessori Education}

The scientific spirit of observation and drawing conclusions inspired Montessori's educational approach: "We must now inspire teachers with the aid of a 'scientific outlook,' but a perspective that is focused to one field, the school" (Montessori, 1988, p. 5). Montessori had harsh criticism for education in schools and kindergartens in her day, and no less for the application of science in the teaching of education. Montessori specifically was opposed to the discipline of education dealing solely with measuring and analyzing the existing situation without engaging for the sake of changing the face of education: "The goal of the science of education cannot be only to measure and to analyze but to change children" (Montessori, 1988, p. 32).

Observing the child lies at the foundation of Montessori's scientific view. When one observes children scientifically, one sees that the goal is: "release of the life chained by endless obstacles that bar their harmonious development, both physically and spiritually..." and from here: "the fundamental demand of the program for scientific education is school and learning that enables the child to develop his independent life freely... let us say, from observing free children..." (Montessori, 1988, p. 19).

One must remember that Montessori initially worked and conducted experiments with children with special needs. In addition to her scientific education and her belief in the importance of correct application of scientific principles in education, she drew her principal source of inspiration from two people: Jean Marc Gaspard Itard (1774-1838) and Édouard Séguin (1812-1880).

Montessori was influenced deeply by Séguin's research. She even took upon herself to translate and copy by hand into Italian his large and important work in order to understand it better. Montessori dove deeper and deeper into Itard's and Séguin's books and work methods, and claimed that educators misunderstood them and certainly did not apply their educational principles (Montessori, 1988; 1912, ch. 2). As an example of optimal educational environment, Montessori notes Itard's and Séguin's contribution from their work with children with disabilities to her theory of creating the special learning tools that characterize Montessori education (Montessori, 1988; 1912, ch. 6).

Thus, Montessori education is the independent creation of an educational personality with a vision, who based her work and methods on observations and examinations of children. Nonetheless, it is clear from Montessori's writings, particularly her introductory chapters (Montessori, 1988; 1912, ch. 1, 2), that her approach corresponds both to the educational approach of individualism and of acculturation (Lamm, 2002). We will see below that the methodological approach of the Montessori school is based first and foremost on individual learning and pace. However, Montessori also had great respect for different subjects and cultural and traditional values, and she emphasized humane values and knowledge as the key to individual fulfillment (Montessori, 1988). The word God, for example, appears numerous times in her writings (Neill, in contrast, was an atheist and saw in religion and everything connected to it one of the most difficult problems of culture and education). 


\subsection{Waldorf Education}

As we have seen, Waldorf education, like Montessori education, was created from the work and vision of one person: Rudolf Steiner. Steiner had expertise in scientific knowledge and methods of his day, and although he had not studied psychology and education formally, his lectures and writings are testimony to his comprehensive knowledge of those fields as well (Zander, 2007). Despite his background, Steiner was ambivalent about the scientific spirit of his day. He admired the sciences and technological developments of his period, yet claimed that they led humans to a dead end. He opined that one should also direct the scientific state of mind to fields beyond physical matter and associated research. Anthroposophy, the spiritual teaching that he originated, was an attempt to create spiritual knowledge, whose source was in high-level and transcendent literature about humans and about the universe (Steiner, 1972).

From here, it is evident that Steiner viewed science as given to development, and that this development would soon lead to knowledge of "upper" or "hidden" fields of awareness. In his opinion, the world of ordinary consciousness is but a tiny part of a much larger world where the answers to deep questions of human existence lie hidden (Steiner, 1947, 1971; and in the framework of a philosophical discussion, Steiner, 1986).

Waldorf education is based on the books, lectures, and research of Steiner, on a period of years when he accompanied a school as its principal (Steiner, 1975), and on his successors who continue to work and research today. This is, one can say, an educational path based upon a spiritual outlook: anthroposophy (Goldshmidt, 2019). The fact that Waldorf education rests upon a spiritual worldview that is not given to empirical proof and springs from the personal spiritual vision of one person generated numerous critics of the educational movement (Bierl, 2005; Zander, 2007). Many critics distinguished between Steiner's research methods and spiritual teaching, which they could not accept, and the practice of Waldorf education (Bierl, 2005; Zander, 2007).

The spiritual support upon which Waldorf education rests also makes it impossible, in my opinion, to categorize it under one of the three accepted ideological paths: social-based learning, culture-based learning, and individual-based learning (Egan, 1977; Lamm, 1976). The spiritual aspect of Waldorf education is, seemingly, "above" the three overarching goals of these educational approaches. It springs from a different source, seeing the child as a spiritual being, the teacher as a person developing spiritually, and in school education a means for spiritual development of all involved in the task, both in the present and as future potential (Goldshmidt, 2019).

\section{Fundamental Educational Principles}

\subsection{Democratic Education}

In his book Summerhill, A. S. Neill, founder and director of Summerhill, established in 1921 as the first school in the spirit of democratic education, articulated very clearly, "When my first wife and I began the school, we had one main idea: to make the school fit the child - instead of making the child fit the school." (Neill, 1960, p. 8). For this purpose, it was clear 
to Neill that they must "establish a school in which we would give the children the freedom to be themselves." This position has tremendous significance for the teacher: "In order to do this, we had to renounce all discipline, all direction, all suggestion, all moral training, and all religious instruction" (p. 9). It follows that the adult, the teacher, the counselor, the educator becomes a person of dialogue, a partner with no hierarchical status. Everything, according to Neill (and most of his successors), springs from this belief: "All it required was what we had - a complete belief in the child as a good, not an evil, being. For almost forty years, this belief in the goodness of the child has never wavered; it rather has become a final faith" (Neill, 1960, p. 11). Daniel Greenberg, founder of Sudbury Valley School in Massachusetts, presents the motto of his work similarly: "The starting point of our thinking was the revolutionary idea, apparently, that the child is a person worthy of the full respect of a human being" (Greenberg, 1994, p. 13).

The democratic approach essentially turns the school into a workshop for democratic life (Hecht \& Ram, 2008; Kiezel, 2012). Thus, there is a fit between the educational goals and the means used to achieve them. The school must become a microcosmos of democratic life, such that the students are full partners and have equal rights in all processes occurring in it (Hecht \& Ram, 2008; Kiezel, 2012). The students are equated with adult citizens in society in every practical and learning aspect. Experimenting with democratic life includes:

- Respect for the student and demonstration of openness and patience with the student's beliefs and internal freedom.

- Full authority and management of student institutions: Institutions for independent student rule, including positions, committees, and free elections.

- Establishment of a parliament as the highest school institution, in which the students have equal rights with teachers.

- Formulation of a school constitution, including full and equal rights between students and between students and teachers.

- Establishment of three separate authorities for legislation, judgment, and management of the school.

- Freedom of choice between subjects and/or overall learning processes (Hecht \& Ram, 2008; Kiezel, 2012).

In a traditional school, processes of learning and teaching and the question of knowledge are central to an educational ideology geared toward acculturation. In democratic education, there is a certain indifference to this question. Hecht and Ram (2008) see the first principle of a democratic school in the assumption that no field or body of knowledge is required, and there is no ideal teaching method. Knowledge is none other than an opportunity for personal growth, it is not a value in and of itself, and learning happens everywhere, at all times, even without guidance or structured method. A person is naturally curious, and one must encourage this curiosity in natural ways. Every girl will eventually find the knowledge and methods of learning that suit her, if only given the free time and space to do so (Hecht \& Ram, 2008). The practical applications of these principles will be discussed below. 


\subsection{Montessori Education}

Montessori believed with all her heart in the tremendous potential concealed in every girl and boy and in the broadest possible nurturing of their abilities and possibilities. She saw children as being autodidactic; thus, both the learning theories and methods she developed were based upon internally driven, independent investigation. Instead of transferring information and an atmosphere of reward and punishment, Montessori sought to nurture the independent learner and life skills in social, emotional, intellectual, and practical spheres (Cloe, 2017; Montessori, 1973, 1988). The key terms in Montessori education are:

\subsubsection{Respect for the child and belief in their hidden potential}

"From one perspective, it is Montessori's approach is based upon trust in the strengths and abilities of the child. From here the great emphasis on experimentation, sensory play and creativity, on supervised choice, and on maximum freedom of action in a framework of clear boundaries" (Lillard, 1972; Montessori, 1973, 1988).

\subsubsection{Freedom and skilled choice}

The educational environment in Montessori education is designed in such a way that every child has freedom of activity appropriate to their motor, emotional, and cognitive development. The learning is individual and occurs in a rising spiral framework of skills in different fields of learning. The learning environment encourages free choice within a clear framework of activities and aids (Lillard, 1972; Montessori, 1973, 1988).

\subsubsection{Development of independence}

Montessori education encourages children to experiment and to learn independently, to solve problems and overcome obstacles in different fields without help from adults or with as little help as possible. Learning methods and tools (see below) are based on independent, experiential learning and on mechanisms for independent supervision (Lillard, 1972).

\subsubsection{Environment as educational factor}

Montessori developed and enhanced learning tools that Sagan began implementing in his work with children with special needs (Montessori, 1973; 1988). She called this a "prepared environment" or "designed environment" and meant that the educational environment should influence the children's development in desired directions. For every field of learning (see below), Montessori designed a complex series of learning tools with which children learn and nurture their talents in different levels (Montessori, 1973; 1988).

\subsubsection{Role of the educator}

Montessori changed the term "teacher" to "guide". In the Montessori method of instruction, children learn independently and the educational guide only observes them, assisting when necessary. The guide does not "transmit material," teach frontally or lecture. Essentially, the guide must simply pay attention that the child is learning independently: "The educator must work hard to ensure that it will be easy for the child to work hard" (Montessori, 1973; 1988). 


\subsubsection{Sensitive periods}

Montessori divided childhood into three major periods: from birth to age six, from 6-12, and from 12-18, each period with its own developmental challenge. The most significant stage of child development occurs from birth to three, the stage of the "absorbent mind," when the child is in "spiritual embryo," followed by being in "social embryo" (until age six). The second stage, until age 12, is the age of learning, of absorbing facts and knowledge, the social age, and the age at which consciousness and awareness of moral questions exists. The final stage, until age 18, is the stage of sexual maturity, independence, and sensitivity and responsibility to the surrounding world. Montessori called adolescents in this stage "children of the earth" (Lillard, 1972; Montessori, 1973, 1988).

\subsubsection{Multi-age classroom}

Montessori derived her model of the multi-age classroom with three grades in each class from her observations. The multi-age classroom is based on the principle that children can help each other and gain from multi-age learning emotionally, socially, and cognitively (Lillard, 1972; Montessori, 1973, 1988).

\subsubsection{Learning tools}

An essential component of Montessori education is the learning tools that Montessori designed and developed. The tools are intended for the individual, free play of children and express the essence of the idea of independent, creative, and sensory learning. The learning tools are designed in accordance with the different fields of knowledge: life skills, mathematics, natural sciences, language, geography, and art (see below; Montessori, 1973; 1988).

\subsection{Waldorf Education}

Waldorf education is based on a developmental perspective formulated by Steiner (Steiner, 1965, 1996). This perspective, which shares central principles with others, Piaget, Erikson, and Kohlberg (Ginsburg, 1982), rests upon Steiner's spiritual research as noted above. According to Steiner, childhood contains three major periods; in each, development of the child rests upon different internal and external qualities. Similar to Piaget and Erikson, Steiner views the stages of development as building slowly, such that each stage is based and built upon the previous one. To the extent that the development stage is exploited and the developmental challenge met, the subsequent stage can develop appropriately (Easton, 1997).

During the first seven years, the child's developmental emphasis is on sensory experience, movement, activity, and imaginative, free play (Steiner, 1965, 1996). Steiner views intellectual education, abstract knowledge, and academic learning at this age as harmful to a child's development and principle task: building the physical body in its broadest sense (Steiner, 1965, 1996). During the period Steiner labels "middle-childhood," from the age of 6-7 to 13-14, he opines that emphasis should be placed on nurturing the mental-emotional experience of the child, on fostering their social connections and skills and on strengthening and encouraging imaginative and creative abilities (Steiner, 1965, 
1996). During the next seven years, from age 13-14 to 20-21, emphasis should be placed on informative and inspiring learning about the world, on social activity, on initiative and activity in different creative fields, and on strengthening and nurturing the personal identity of each adolescent (Steiner, 1965).

In accordance with this developmental scheme, there is no simple, definitive response in Waldorf education to the great educational questions, rather they are placed on the developmental axis. Thus, for example, questions such as: the relationship between the educator and the child, the question of student freedom and choice, learning methods and tools, the place of the individual in the group, and more, undergo change and even transformation during the years from kindergarten to the end of high school (Steiner, 1965).

In addition to the principle of development, Steiner emphasizes what he calls "education of the whole person". His intention is to afford children the broadest and most multi-faceted and open experimentation as possible in every stage of education, from kindergarten until the end of high school. In Waldorf schools, children perform a variety of experiments in diverse fields of activity - with no hierarchy (Edmunds, 2012).

Additional essential characteristics applied in Waldorf kindergartens and schools are: attention and nurturing of the aesthetic, whether in the schoolyard or in the classroom, sensitivity to natural materials (natural wood, rugs, cloths, craft materials, nutrition and more), learning processes based upon human connection without mediating devices until adolescence, long-term accompaniment of the class by the same educator, educational continuity from kindergarten through the end of $12^{\text {th }}$ grade, integration of children with special needs in different school frameworks, and shared management by the teaching staff rather than hierarchical management (Easton, 1997; Edmunds, 2012).

\section{Educational Practice}

\subsection{Democratic Education}

In contrast to Montessori and Waldorf education, the democratic education movement is very diverse ideologically and in practice. The movement's affinity to liberal philosophy with its focus on the centrality of the child, coupled with varied understandings for implementing its principles, lead to the branding together of diverse schools and educational methods (Kiezel, 2012).

Schools that call themselves democratic apply the principles of democratic education differently and to varying extent: respect for the child as an autonomous being and placement of the child's needs, wishes, and desires at the center; freedom of choice, institution of democratic life at school (separation of authorities, parliament as sovereign body, judicial institutions in partnership with/management by students, student executive bodies); and interpersonal dialogue as the basis for relationship and learning processes. I see three primary models in the field, each with internal variation: 
1. Public schools in which the climate and majority of learning processes and methods are in accord with education ministry requirements and procedures, alongside elements of democratic education ideology. For example, autonomous student committees in certain areas; one to two-hour class periods in the daily schedule dedicated to student choice; foundation of conversation and dialogue in the area of discipline, and more.

2. Democratic schools by definition, applying democratic education principles in accord with its unique worldview. Generally, there are scheduled lessons and teachers teach fields of knowledge, with students choosing from among the different fields and activities, with no age distinction. The principle of separation of powers is implemented within certain limitations (usually in the form of a constitution). Significant scope is given to student decision making and free space. Similarly, emphasis is placed on guiding processes of students by educational staff (Hecht \& Ram, 2008). In Israel today there are about 25 schools that define themselves as democratic in this spirit.

3. Schools in the spirit of "Sudbury" (Greenberg, 1994) where there is no set daily schedule, no curriculum, and no teacher-generated activity or initiatives. There are also no adult staff initiated, organized guiding processes. The school runs by student initiative alone. Lessons and activities happen only if the students want and initiate them. For the teaching staff, its purpose lies only in supporting and guiding the students. In this model, there are no classrooms or significance to children's ages with regard to different activity areas. Separation of powers and bodies exists at these schools: parliament, discipline committees, and the like, through which the students manage themselves (Greenberg, 1994). As of 2020, five schools in Israel self-defined as being in the spirit of Sudbury.

The outstanding feature of democratic schools, particularly in the last two models, is the positive atmosphere, the freedom, and the personal, warm, and open relationships among the children and between students and teachers, relationships based on trust and respect. There is great weight given to free play and to games organized by the children themselves, learning processes stem from the basic and natural curiosity and desire of the children to learn and know. However, as I will expand upon below, no emphasis is placed upon unique or age-specific developmental learning processes, there are no unique teaching methods, and when formal learning takes place, its format is similar to that of public schools, including use of the same textbooks.

\subsection{Montessori Education}

The majority of learning processes in Montessori kindergartens and schools happens individually. The students are engrossed in the educational tools and learn through them. The tools are arranged aesthetically and are accessible to the children (at appropriate height and arrangement) on long shelves in the class space. The students use them when they desire, at their own pace, and under guidance from the educational staff. (Lillard, 1972; Montessori, 1912). 
Montessori set the following school subjects: natural sciences, geography, mathematics, language, life skills, and the senses. Each field employs learning tools based upon the increasing, spiral development of the child's skills. The tools were developed to enable children to learn from their mistakes and correct them: The children, themselves, determine how and where to take the next developmental step. Students have broad freedom to organize their learning and to choose what they want to learn, and when and where within the classroom space (Lillard, 1972; Montessori, 1912).

At every age, particularly the youngest, Montessori learning processes are based on doing, activity, and sensory experiences. For example, the students experience planned, ordered sensory experiences: smelling aromas, assessing weight, listening to bells, sampling a variety of tastes, and ranking these experiences or organizing them into groups. Mathematics is learned beginning with tools that bring the idea of the number as a sensory experience of touch or sight. The letters of the alphabet are learned by feeling the shapes of the letter on fine sandpaper and the like. Processes of abstract cognition are always executed after sensory experiences and physical experimentation (Lillard, 1972; Montessori, 1912).

As noted, Montessori changed the term "teacher" to the term "accompanier" or "guide." Members of the Montessori educational staff see themselves more as adult guides assisting students in their studies, and only when needed and if the students reach a dead-end in their independent work. Throughout the world as well as in Israel, Montessori education is more established in preschool education, the age with which Montessori, herself, began working, and less in secondary schools. As of the year 2020, about 40 Montessori-styled kindergartens and 10 elementary schools operate in Israel (https://israel-montessori-magazine.com).

\subsection{Waldorf Education}

In contrast to democratic and Montessori education, in Waldorf education, child development is the foundational principle upon which educational practice is based. Hence, it is necessary to describe the educational practice from the three different agerelated points-of-view: the first seven years from birth through kindergarten, the second seven years of elementary school age, and the third seven years of secondary school.

Waldorf-styled kindergartens emphasize free, imaginative play; commonsense goal-oriented activity such as baking bread, cooking, sowing and knitting, and vegetable gardening; free, artistic creativity; and reoccurring rhythms throughout the day, week, and school year. Kindergarten teachers work by imitation, such that as many possible activities are executed without instructions or conscious, thought processes, rather simply through imitating and doing (Edmunds, 2012; Steiner, 1996).

In elementary school, to the extent possible, diverse art processes are central to educational activity: singing and playing the recorder, recitation and drama, painting and drawing, sculpting with different materials, and the artistic movement unique to Waldorf schools called "eurythmy", both as exercise and artistic experimentation and as an instructional method for different subjects (Goldshmidt, 2017). Steiner hoped that 
through inspirational artistic activity students would be exposed to and acquire essential knowledge (Goldshmidt, 2017). The world of stories is also central to student learning processes. Stories speak to the world of feeling and experience, the place in which, according to Steiner, development at this age is meant to occur (Steiner, 1996).

Instruction is carried out by class with an emphasis on the members as a social group. The style of teaching is diverse, characterized by frontal teaching, small group learning, and individual learning. In Waldorf schools at this age there is no choice, there is a clear daily schedule with all the children learning the same lessons. During and between lessons, the children receive tremendous personal attention with the teachers accounting for individual needs, yet the learning generally occurs as a class and is not given to individual choice (Easton, 1997).

Secondary schools emphasize integration of workshop, art, and theory in different subject areas, individual and group projects, social activism, and diverse social processes in the classroom, with the larger peer group and the entire high school. At this stage, there is more choice and the freedom to choose one's own path expands.

In 2020, over 100 kindergartens, 30 schools, and eight teacher training programs in Waldorf style education are operating in Israel.

\section{Critique}

In their uniqueness, the three alternative movements of education discussed here face two central critiques. The first is violation of the principle of equality represented by public education. The alternative movements create frameworks of elitist education for children of established families, frameworks that have student selection procedures and relatively high tuition. When students from affluent families leave public schools for alternative schools, they harm the public schools (Kiezel, 2012). This critique sees the establishment of alternative schools as part of the global privatization trend that characterizes the neo-liberal state of mind. In its framework, services provided for by the state in the past are now provided for by competing, private bodies. For many parents, the unique schools are seen as refuges from integration and are directed to separation and educational-social elitism.

The second line of critique common to all three movements is the claim that while they perhaps nurture meaningful human values and place the child at the center of educational practice, they do not prepare their students for life in the contemporary, competitive, goal-driven reality found outside the school walls (Baumann-Bay, 2000; Bierl, 2005).

\subsection{The Similar and Dissimilar in the Three Movements}

I see the following qualities as common to the three movements, even if each applies them differently in accordance with the ideology and traditions created within its framework:

1. Child-centered approach: The child is the center of educational activity, around them and for them are educational and instructional processes and managerial 
and organizational school frameworks. This approach stems from belief in the potential hidden in every girl and boy and the possibility of realizing that potential.

2. Focus on the present: Focus on the here and now, on what is important to the child at this moment (whether on what the child says and chooses or whether from supporting ideology) that is likely to assist the child's physical, mental, and spiritual development and flourishing.

3. Holistic approach to educational and instructional processes: Creation of a rich and varied educational and learning environment to the extent possible given the approach that "everything is important." From this approach stems the absence of hierarchy in the fields of knowledge and activity.

4. Diverting the focus from theoretical and rational fields to fields of doing, creating, art, and sensory experience.

5. Viewing learning processes and acquiring knowledge as a means of leading to the child's development, to self-fulfillment, and to strengthening the potential hidden within rather than as a goal in and of itself. Knowledge, itself, is less important than the process the child undergoes in the framework of learning.

6. Teachers as educators and not as agents of knowledge. From this principle stems the relative autonomy and freedom of teachers to act as they see fit and appropriate for the circumstances and the children with whom they work.

7. School autonomy and relative freedom from requirements of the educational establishment. This is also true for schools that are public in part (unofficial recognition) as well as for state schools.

8. Implementation of nonhierarchical management, each movement with its different approach.

9. Alternative evaluations for approaches to the humanities without standard grades and exams.

In order to clarify the different lines between the movements, I will present five central axes. Each axis represents an educational quality that moves between two extremes. Each educational movement described in the article is found on a different point on the axis.

\subsection{Obligatory framework and teacher authority -------------- Free choice and autonomy of the child}

Democratic education

By its nature and essence democratic education is found at the extreme of autonomy and choice.

Montessori education

Montessori education integrates required frameworks and free choice and autonomy in its learning methods.

Waldorf education 
The developmental line in Waldorf education creates a reality in which students learn in authoritative and obligatory frameworks at young ages, which become more relaxed such that authority and choice transfer to the students themselves in secondary school.

\subsection{Importance of childhood and its nurturing child as an adult}

Perspective of the

Democratic education

When the viewpoint of respect for the child signifies transferring to the child choice, authority, and management of the school, we essentially relate to the child as an adult.

Montessori education

Montessori education is found in the center of the axis. The framework of learning methods relates to students as mature, as independent, autonomous learners and. However, the educational staff has authority over management and organization of the school.

\section{Waldorf education}

In the various Waldorf educational frameworks, tremendous respect is given to the abilities of the children and the effort to nurture and protect them.

\subsection{Education as a profession}

Every person is an

\section{educator}

\section{Democratic education}

In democratic education, particularly in its most extreme forms, every life situation and every human encounter is an educational and learning experience.

Montessori education

Waldorf education

In both Montessori and Waldorf education there is great significance placed on the teacher's professionalism and to targeted training both in fields of knowledge and in the principles and methods of the educational movement.

\subsection{Importance of teaching methods --------------- Emphasis on multiple forms of personal learning}

Democratic education

Most of the literature does not note teaching methods. Learning method is not so important, as long as the learner desires to learn, they will find their way to knowledge.

Montessori education

Waldorf education

In both Montessori and Waldorf education, teaching methods are of the utmost importance. 
5.6 Group learning processes

Personal and independent learning processes

Democratic education

Montessori education

Both democratic and Montessori education emphasize personal learning, both as a matter of choice and of the student's internal drive.

Waldorf education

In Waldorf schools, at least until high school, group learning is essential to the spirit of the school. Emphasis is placed on students learning from one another, on the building of "group learning spirit" and on social processes within the class group.

\section{Conclusion}

This article surveys three alternative educational movements: Democratic education, Montessori education, and Waldorf education. I presented the history of the establishment and founding educator of each movement, their theoretical-philosophical foundation, their educational principles, educational practices, a critique of the movements and, finally, their similarities and differences. The article attempts to give an overarching view; hence, there is a need for future articles that will examine each of the criteria brought here for a more in-depth and critical discussion.

\section{References}

Bailey, R. (2013). A. S. Neill. London: Bloomsbury.

Baumann-Bay, L., \& Baumann-Bay, A. (2000). Achtung, Anthroposophy! Zuerich: Kreuz Verlag.

Bierl, P. (2005). Wurzelrassen, Erzengel und Volksgeister. Berlin: Konkret Literatur Verlag.

Chloë, M. (2017). Montessori education: A review of the evidence base. npj Science of Learning, 2(1), 1-9.

Dewey, J. (1916). Democracy and education. Boston: Macmillan.

Easton, F. (1997). Educating the whole child 'head, heart and hands': Learning from the Waldorf experience. Theory into Practice, 36, 87-95.

Edmunds, F. (2012). An introduction to Steiner education: The Waldorf School. London: Sophia Books.

Egan, K. (1997). The educated mind: How cognitive tools shape our understanding. Chicago: University of Chicago Press.

Ginsburg, I. (1982). Jean Piaget and Rudolf Steiner: Stages of child development and implications for pedagogy. Teachers College Record, 84, 327-337.

Goldshmidt, G. (2017). On the unique place of art in Waldorf education. European Journal of Education Studies, 3(8), 36-50. 
Goldshmidt, G. (2019). Meditation with children: Is it appropriate to do reflective and meditative activity with children in schools. Religion $\mathcal{E}$ Education, April, 45-60.

Greenberg, D. (1994). Kingdom of childhood: Growing up at Sudbury Valley School. Framingham, MA: Sudbury Valley School Press.

Greenberg, D. (2016). A place to grow: The culture of Sudbury Valley School. Sudbury Valley School Press.

Hemleben, J. (1984). Rudolf Steiner. Rowohlt: Reinberk bei Hamburg.

Kizel, A. (2012). The democratic selective education in Israel: Tikkun olam or separatism. Studies in Education, 6, 46-61 (Hebrew).

Korczak, J. (1967). Selected works of Janusz Korczak. (Selected from Polish by Martin Wolins, Trans. Jerzy Bachrach). Washington: Technical and Economic Information, Warsaw.

Lamm, Z. (1976). Conflicting theories of instruction conceptual dimensions. New York: McCutchan Publishing Corporation.

Lifton, B. J. (1988). The king of children: A biography of Janusz Korczak. New York: Farrar, Straus \& Giroux.

Lillard, A. S. (2013). American Journal of Play, 5(2), Winter, 157-186.

Lillard, P. (1972). Montessori: A modern approach. New York: Schocken Books.

Mary, B. H., \& Chester, M. R. (Eds.). (1988). Passion of youth: An autobiography. Farrar, Straus and Giroux.

Miller, R. (2007). What is democratic education. In The Directory of Democratic.

Montessori, M. (1912). The Montessori method. New York: Fredrick A. Stocks Company.

Montessori, M. (1973). From childhood to adolescence. New York: Schocken Books.

Montessori, M. (1973). The Montessori elementary material. New York: Schocken Books.

Montessori, M. (1988). The discovery of the child. Oxford: Clio Press.

Neill, A. S. (1960). Summerhill: A radical approach to child rearing. New York: Hart Publishing Company.

Neill, A. S. (1972). Neill! Neill! Orange Peel! New York: Hart Publishing Company.

Rousseau, J. J. (1921). Emile, or on Education, trans. by B. Foxley. London \& Toronto: J. M. Dent and Sons.

Silverman, M. (2017). A pedagogy of humanist moral education: The educational thought of Janusz Korczak. New York: Palgrave Macmillan.

Standing, E. M. (1957). Montessori: Her life and work. New York: New American Library.

Steiner, R. (1947). Knowledge of the higher worlds and its attainment. New York: Anthroposophic Press.

Steiner, R. (1965). The education of the child in the light of anthroposophy. New York: Rudolf Steiner Press.

Steiner, R. (1971). Theosophy an introduction to the supersensible knowledge of the world and the destination of man. New York: Anthroposophic Press.

Steiner, R. (1972). An outline of occult science. New York: Anthroposophic Press.

Steiner, R. (1975). Faculty meetings with Rudolf Steiner, trans. R. Lathe \& N. Whittaker. Konfernzen, Dornach: Rudolf Steiner Verlag. 
Steiner, R. (1986). Mein Lebensgang. Dornach: Rudolf Steiner Verlag.

Steiner, R. (1996). The education of the child. New York: Anthroposophic Press.

Troyat, H. (2001). Tolstoy. London: Grove Press.

Wills, W. D. (1964). Homer Lane: A biography. London: Allen \& Unwin.

Zander, H. (2007). Anthroposophie in Deutschland. Goettingen: Vandenhoek \& Ruprecht.

Zweig, S. (1964). The world of yesterday. University of Nebraska Press. 
Gilad Goldshmidt

THREE STREAMS IN ALTERNATIVE EDUCATION: A PHILOSOPHICAL, PEDAGOGICAL, AND PRACTICAL COMPARISON BETWEEN DEMOCRATIC, WALDORF, AND MONTESSORI EDUCATION

Creative Commons licensing terms

Authors will retain the copyright of their published articles agreeing that a Creative Commons Attribution 4.0 International License (CC BY 4.0) terms will be applied to their work. Under the terms of this license, no permission is required from the author(s) or publisher for members of the community to copy, distribute, transmit or adapt the article content, providing a proper, prominent and unambiguous attribution to the authors in a manner that makes clear that the materials are being reused under permission of a Creative Commons License. Views, opinions and conclusions expressed in this research article are views, opinions and conclusions of the author(s). Open Access Publishing Group and European Journal of Alternative Education Studies shall not be responsible or answerable for any loss, damage or liability caused in relation to/arising out of conflict of interests, copyright violations and inappropriate or inaccurate use of any kind content related or integrated on the research work. All the published works are meeting the Open Access Publishing requirements and can be freely accessed, shared, modified, distributed and used in educational, commercial and non-commercial purposes under a Creative Commons Attribution 4.0 International License (CC BY 4.0). 